\title{
Producing the Greatest Good for Greatest Numbers-Implementation of Utilitarianism Principle: The Case Study of Producing Recombinant Protein of JDV
}

\author{
Menghasilkan Bahan Paling Baik untuk Jumlah Sangat Besar-Penerapan Prinsip \\ Utilitarianisme: Studi Kasus Produksi Potein Rekombinan JDV
}

\section{Endang Tri Margawati}

Research Centre for Biotechnology, the Indonesian Institute of Sciences (LIPI)

Jl. Raya Bogor KM. 46, Cibinong 16911

E-mail: etmargawati@cbn.net.id

\begin{abstract}
Advanced technology in molecular biology often uses microorganism, consequently, researcher should have a responsibility in producing of laboratory products safely both for human and their environment. This presentation was intended (1) to report recombinant protein research in the Jembrana Disease Virus (JDV); (2) to identify relevancy of the ethics towards the research of recombinant protein and (3) to discuss relationship of utilitarianism principle with the development of the recombinant protein. The Jembrana disease is an infectious virus caused by a virus classified as retrovirus of Retrovidae family. The disease only attacks Bali cattle (Bos javanicus) that caused about $20 \%$ mortality rate. Up to present, crude vaccine from lymph organ of acute infected Bali cattle is often used for vaccination. Development of the Jembrana vaccine was attempted to increase the availability of qualified Jembrana vaccine by recombinant DNA approaches subsequently could be used as vaccine substances. This article was presented with much bioethics issues in associated with recombinant protein research and other examples of related research which use micro-organism in their investigation. It is expected that bioethics could be a restrain for researchers who deal with advanced technology in their investigation.
\end{abstract}

Key words: Utilitarianism principle, recombinant vaccine, Jembrana disease, Bali cattle

\begin{abstract}
Abstrak
Teknologi maju pada biologi molekuler sering menggunakan mikroorganisme, maka peneliti dituntut untuk menghasilkan produk laboratorium yang aman baik untuk manusia maupun lingkungannya. Penelaahan ini dimaksudkan untuk (1) melaporkan penelitian protein rekombinan pada virus penyakit Jembrana; (2) mengidentifikasi relevansi dari segi etik terhadap penelitian protein rekombinan dan (3) membahas hubungan prinsip utilitarianisme dengan pengembangan vaksin rekombinan. Penyakit Jembrana adalah penyakit infeksi dan mematikan, disebabkan oleh virus kelompok retrovirus dari keluarga Retrovidae. Penyakit ini menyerang khusus sapi bali (Bos javanicus) dan menyebabkan rata-rata kematian fatal $20 \%$. Sampai sekarang, crude vaccine dari organ lymfa sapi bali terinfeksi akut penyakit jembrana digunakan untuk vaksinasi. Pengembangan vaksin Jembrana diusahakan untuk meningkatkan ketersediaan vaksin Jembarana berkualitas dengan pendekatan teknologi DNA rekombinan selanjutnya dapat digunakan sebagai bahan vaksin. Artikel ini disajikan dengan banyak isu bioetika dalam hubungannya penelitian protein rekombinan dan contoh penelitian lain berkaitan menggunakan mikroorganisme. Diharapkan bioetika dapat menjadikan pengerem peneliti yang menggunakan micro-organism dalam menjalankan penelitiannya.
\end{abstract}

Kata kunci: Prinsip utilitarianisme, vaksin recombinan, penyakit jembrana, sapi Bali 


\section{Introduction}

In $17^{\text {th }}$ century, Aristotle had focused on scientific concerns, and the science has progressed rapidly and more widely in molecular biology. Nowadays there are several societies emerging concomitantly with the rapid progress of advanced technology in some specific science interests. In the beginning of $21^{\text {st }}$ century, the progress of science and sustainable development of societies are very dependent of each other (Airaksinen, 1995). It was discussed in the Societas Ethica meeting of science and development progress of societies have warned us that ethics and science have become important elements for both interests of science and those of society. It is as reminded by Behm (2005) that research ethics is recognized widely as an important feature of scientific practice. There are three human interests towards knowledge, those are technical, practical and emancipatory (Habermas, 1971). Technical interests can be found behind natural sciences and behind some systematic social sciences, practical interest lies behind humanistic sciences while emancipatory interest lies behind critical social sciences. Based on the Haberman's interests, it is clear that researchers need to perform their research works wisely and responsibly for living organism and environment.

When researchers deal with research using living organism or something alive then they need to be concern with bioethics. There are many definitions of bioethics, most of them control the effect of research works to human and environment. However, when we line up with focus on research purposes then we get the same red line that we need to be aware to the environment in wider meaning.

Have you been thinking that someday life in the world could be extinct due to no medicines for recovering or healing illness? In one side, the existence of advanced technology is based on molecular level offering ease, efficiency and little expense in terms of mass production. In other side, there is still a gap of fear resulting from breakthrough of the advanced technology. Mankind have been granted mind and soul, in the other hand, they also need to improve a high qualified, cheaper, safer and useful medical material for a wider mankind.

Starting from the above statement, bioethics comes in the middle of a higher life demand that has to be fulfilled for sustainability of their life. Therefore, the definition of bioethics needs to be understood carefully and wisely. Bioethics is a combine of several disciplines of knowledge concerning on ethics, legality and social questions (worries) that emerged as the effect of development in medicines, science and biotechnology (Mepham, 2005). Advances in science with molecularbased technology as a tool, this will be useful to cope with the lack of food and medicine availability, as long as the advanced technology and material research are chosen wisely. This option of doing research meets to the definition of bioethics which is stated as the study of moral and social implications of techniques resulting from advances in the biological sciences (Mepham, 2005).

As stated by first bioethicist of Aldo Leopold that "A thing is right when it tends to preserve the integrity, stability, and beauty of the biotic community. It is wrong when it tends otherwise" (Leopold, 1949). This statement reminds us that human being should be responsible in using the natural sources wisely. Another definition stated that bioethics is actually not a discipline, but it has become a meeting ground for a number of disciplines, discourses, and organizations concerned with ethical, legal, and social questions raised by advances in medicines, science, and biotechnology (O'Neill, 2002; Mepham, 2005). Those definitions are clear that both concerned with implication of using of advanced technology for producing huge number of medical products.

Creating biological medicines is also needed for animal welfare as another organism on earth, which will be discussed in this article as a case study in producing vaccine. Entering biotechnology era, it is very possible to develop the Jembrana vaccine by applying a recombinant DNA technology to produce recombinant viral protein as a recombinant vaccine for controlling the Jembrana disease in Bali cattle.

As local beef cattle in Indonesia, Bali cattle are recognized as one of gene pools beef cattle in South-East Asia, it has superiority in 
reproduction of one year in calving interval. In spite of that reproductive superiority, Bali cattle have other superiority in meat characteristics, i.e., lean, juicy and smooth texture of muscular fiber. However, Bali cattle have inferiority in susceptibility of Jembrana disease virus (JDV), Chadwick et al., (1995). The fatal mortality rate of Jembrana disease was recorded about $20 \%$ in 1964 (Moll, 1998). In the past colonization by Dutch, Bali cattle were restricted rearing in Bali Island to prevent their genetic purity. By the time and up to present, distribution of Bali cattle is wider throughout Indonesia. The disease is then transmitted to other islands and the need of Jembrana vaccine is therefore increased. Recently, vaccination is performed by using crude tissue-derived vaccine (Hartaningsih and Wilcox, 1996; Hartaningsih et al., 2001). Processing of the crude vaccine is costly, due to using infected lymph or spleen organs of fresh slaughtered Bali cattle. The disadvantage of the crude vaccine is a low quality, expensive, low production, and difficult to handle in the field.

Advancing in recombinant DNA and more popular technology for medicine research is recombinant protein. Jembrana disease virus (JDV) belongs to lentivirus group of Retroviridae family (Wilcox et al., 1995). The JDV genome (7732bp) consists of at least three major genes (gag, pol and env) encoding proteins that needed for virus replications (Chacdwick et al., 1995). Moreover, it was stated that the env gene encodes TM and SU proteins on the surface of the virus and most attempts to induce a protective immunity against lentivirus infection. Another immunogenic viral protein is Tat that is coded by tat gene. The tat gene is one of small accessory genes and lies between gag and pol genes. In recent study, those three Jembarana genes were cloned into a plasmid vector in a pGEX system. The obtained clones were transformed through a host cell of Escherichia coli (E. coli) to express their recombinant proteins. The host cell of E. coli is very common in expression of recombinant protein since they can multiply quicker in cell numbers bearing the recombinant proteins. Therefore, most recombinant protein is always purified from $E$. coli after cloning on the gene into expression vectors (Studier and Moffatt, 1986).

\section{A Case Study on Recombinant Protein Research in Jembrana Disease Virus (JDV)}

At least three proteins of SU (superficial unit), TM (transmembrane) and Tat were considered as potential candidates for a protective vaccine against Jembrana disease for Bali cattle (ACIAR report, 2004). The TM and SU proteins were encoded by $e n v$ gene while Tat protein was encoded by tat gene. By polymerase chain reaction (PCR), those three gene fragments were amplified then constructed in pGEX system. Therefore, to express proteins the constructs need to be transformed into a host cell of BL21 strain of Escherichia coli as a manufacturer of producing the proteins. Production of the recombinant proteins for JDV is possible as the genes encoding the proteins have been well-characterized (Chadwick et al., 1995).

When cloning of JSU, JTM and JTat were performed using pGEX system in which the proteins were fused with GST tag, the expression and purification of those clones were also conducted in pGEX system. The molecular size of GST tag is $\pm 26 \mathrm{kDa}$ (Amershampharmacia biotech, 1997), while molecular weights of JSU, JTM and JTat are $\pm 34, \pm 10$ and $\pm 10.7 \mathrm{kDa}$, respectively. Therefore, when proteins were fused to the GST tag, they resulte recombinant proteins with size of $\pm 60, \pm 36$ and $\pm 36.7 \mathrm{kDa}$ for JSU, JTM and JTat, respectively. The purification and characterization of those proteins were conducted by SDS-PAGE and Western blotting (WB) methods. Constructing of JTat was also conducted in pET system where the system used a 6-histidine tag which has a molecular size of less than $1 \mathrm{kDa}$. Creating JTat construct in pET system was aimed to increase the efficacy of the resulted recombinant protein of JTat. Expression of JTat was transformed in BL21 E. coli. The protein fused with his-tag canbe purified by chromatography affinity on Immobilized Metal-ion Affinity Chromatography (IMAC), (Bosch et al, 2001).

Those recombinant proteins are the virus attachment protein which initiates the first interaction of the virus and the infected cells. Antibody capable of binding with the protein will be likely preventing the viral infection (Barnett et al., 2001). In the case of JTat 
recombinant protein is a minor protein required by the virus to activate the transcription of the viral genome into mRNA which is necessary for the efficient replication of the virus in the infected host (Cota-Gomez et al., 2002; Wu, 2004). Immune response against the protein is expected to be able to slow down or completely stop the viral replication.

Laboratory scale production was initiated to get a small volume of recombinant proteins which used to field trial in Bali cattle in the disease investigation centre in Denpasar, Bali. Those three recombinant proteins were used in the field trial, and the result showed good response in resulting antibody. Scaling up of the recombinant proteins is needed to be conducted in a manufacturer of biomedical industry.

\section{The Relevant of Ethical Features to the JDV Recombinant Protein Research}

In fact, there are only few articles published on the ethical reflections on molecular technology. In biomedical production, it is rather impossible to be produced conventionally in this recent era. For human needs, increasing population in the world would tend to increase the problems in health due to the rapid development of industries for many purposes. The effect of industrial process, increasing transportation and changing the green view of trees into buildings creates pollutant. This implies that the people's health decrease and the needs of medicines increase drastically. The availability of medicines would need to be accelerated to balance with the increase of human population. The discovery in molecular biology technology contributes significantly in increasing wider products such as in agriculture, medicine, energy, etc. In agriculture base, introduction of advanced technology in food production (cereal, paddy, corn, etc.) is the most important and significant in the world. The increasing of animal population is also important as protein source from livestock. This protein source derived from livestock consists of more complete in number of amino acids compared to that protein source from plant. Similar to human, population of livestock can tend to decrease due to infection by some diseases or less feed.

Jembrana disease is an acute, a severe disease and endemic in Bali cattle (Bos javanicus). The disease caused a $20 \%$ case mortality rate after a short incubation period in Bali cattle (Moll, 1998). However, in the later publication, the JDV has infected also to other cattle types and buffalo during experiment and field condition (Soeharsono et al., 1995). Nowadays, preventing to Jembrana disease in Bali cattle has been using crude vaccine for its vaccination (Hartaningsih and Wilcox, 1996; Hartaningsih et al., 2001). The crude vaccine is provided from infected tissue of Bali cattle by Jembrana viruses. Availability of this crude vaccine is limited compared to recent population of Bali cattle in the field. Despite limited in production, the crude vaccine is also costly, less effective and demanding in vaccine maintenance.

Entering biotechnology era, it is possible to develop a conventional vaccine such as Jembrana vaccine by recombinant DNA technology to produce recombinant viral protein as Jembrana vaccine. Development of recombinant protein for potential vaccine was initiated by colleagues at Murdoch University for Jembrana disease virus (JDV). The initiation of producing a recombinant Jembrana vaccine is expected to solve some problems associated with disadvantages of the current crude vaccine. This recombinant Jembrana vaccine is a safer, effective and lower cost in production process.

The consideration of using advanced technology was intended to develop the existing Jembrana crude vaccine that was produced conventionally. The researchers should decide independently in choosing the manner of doing their research as long as it is still safe and follows principles of biomedical ethics. The principles of biomedical ethics as stated by Beauchamp and Childress (2001) consist of respect to autonomy (independency in decisionmaking); justice (fair treatment and equity); beneficence (doing the good thing); and nonmaleficent (to do no harm).

Researchers should concern to the tendency of people population in the world. Based on Malthus Theory (1798), it was featured that world population increasing exponentially: $2,4,8,16$ etc. while food production increasing linearly: 1, 2, 3, 4 etc., then human population in 2002 was 6,137 million $(4,944$ million were in developing countries) with increasing rate of 
$1.3 \%$ per annum. Therefore, it is no point that we have to do something to meet with those world features in order to get a secure living in harmony with nature. The decision of doing something is not easy to implement it to the research as reminded by Abu Ali al-Husain ibn Abdallah ibn Sina (Avicenna), 980-1037 (http://www-history. mcs.standrews.ac.uk/Mathematicians/Avicenna. html, 1999). His statement was "In science, humankind is (still) looking for a harmonious relationship with nature, and seeking to know it and conform to it".

In science, there are many things to be taken and decided with as much as zero risk to meet with goals to create living in harmony. To implement this statement, a researcher will use advanced technology as a tool based on molecular biology; some will work on genetically engineered organism or genetically modified organism. Those laboratory works will increase the productivity of food or medicines. However, researchers should always control of their work in using the tool and research material. It is reminded by first bioethicist Aldo Leopold (1949) that "A thing is right when it tends to preserve the integrity, stability, and beauty of the biotic community. It is wrong when it tends otherwise".

\section{The Integration of Utilitarianism Principle to the Producing of JDV Recombinant Vaccine}

Along with the use of tools wisely, development of Jembrana vaccine was aimed to fulfill the vaccine needs in a large number due to the increase of Bali cattle population. To achieve this goal, researchers do not have to choose the right and a wise tool. A recombinant DNA technology and more precisely recombinant protein technology is an approach to answer the needs of Jembrana vaccine lately.

The aim of using the advanced technology is to construct a specific gene target into a plasmid vector, then it is transformed into an $E$. coli host cell. In the culture, the host cell of $E$. coli will be multiplied in numbers then recombinant proteins are expressed in side of the cells. Methods of SDS-PAGE and Western Blotting are used for characterization and purification of the recombinant proteins. The yield of recombinant proteins through implementation of recombinant DNA technology is extremely in huge number. The product of recombinant proteins is potential as a Jembrana recombinant vaccine. As stated in the previous chapter, those potential recombinant proteins are JSU, JTm and JTat. Those kinds of recombinant proteins are much more qualified vaccine because they are obtained from targeted gene of Jembrana viral genome compared to that of crude vaccine. The crude vaccine is not only expensive in processing since the process has to kill the Bali cattle, which is infected, to get lymph organ but the crude vaccine is also not targeting. It is because we do not know exactly that the killed cattle were infected by the single disease of the Jembrana virus.

Compared to the conventional process to obtain the crude vaccine, the recombinant vaccine has some advantages. The recombinant vaccine can be produced cheaper in mass production, more qualified (because of more targets) and more practical in handling them in the field. This mass production comes along with the increase of Bali cattle population recently which is not only in Bali Island but spread wider throughout Indonesian islands.

In line with the processing of recombinant protein production, recombinant vaccine could be produced in a large yield through $E$. coli. This research act is an implementation of biomedical ethics principles: respect to autonomy, justice, beneficence and non-maleficent (Beauchamp and Childress, 2001). In doing biomedical research, researchers have responsibility for the products therefore they should be careful and always concern with biomedical ethics.

Many medicine products have been processed through GMO (genetically modified organism) or GEO (genetically engineered organism) to get mass production so that people in the world would be safer from illness. Researchers conducting those processes both in the laboratory and in the field trial have to take the safety into account. At least, one of two principles in ethical theory becomes the foundation resulting from the research processes, this is Utilitarianism principle while another is Deontology principle (responsible and entitle of each individual to another individual), (Bentham, 1907; Mill, 1998). There is an integration of producing recombinant protein in a large number 
to the Utilitarianism principle. The Utilitarianism principle follows the concept of producing the greatest good for greatest numbers. The greatest good in such matter is recombinant protein product which is the qualified product with targeted immunity while the greatest numbers are meant as a large yield producing from manufacturing through E. coli as a host cell. Researchers' respect in the laboratory and in the field is expected to create harmony among human being and other individuals.

\section{Conclusion and Suggestion}

Most of research in biotechnology that applies advanced technologies often uses living organism. In vaccine development for Jembrana disease in Bali cattle, a series of research activities was conducted such as constructing a clone then transformed into a host cell of microorganism in order to express recombinant protein in huge numbers. This activity agreed with one principle in bioethics which is utilitarianism principles "Producing the greatest good for greatest". In this case, researchers should be aware that everything produced from their research should be safe for users or animals in this case. Bioethics is therefore should be always reminding researchers to be wise in conducting and resulting creativity in their research.

\section{References}

ACIAR report. 2004. Production of a Vaccine for the Control of Jembrana Disease in Indonesia. Review Report. ACIAR Project No. AS1/2000/ 029.

Airaksinen, T. 1995. The Virtuous Face of the Ethics of Science. In: Gasparski, W. \& Airaksinen, T. (Eds.). Science in Society. Pp. 13-26. IfiS Publisher. Warsaw.

Amershampharmacia Biotech. 1997. GST Gene Fusion System. The $3^{\text {rd }}$ Edition, Revision 2. Amershampharmacia Biotech.

Barnett, A.L., Davey, R.A. and Canningham, J.M. 2001. Modular Organization of the Friend Murine Leukaemia Virus Envelope Protein Underlies the Mechanism of Infections. Proceedings of the National Academic of Science, USA, 98 (7): 4113-4118.
Beauchamp, T.L. and Childress, J.F. 2001. Principles of Biomedical Ethics. $5^{\text {th }}$ edt. Oxford University Press. UK. Pp. 454. ISBN 0-19-514332-9.

Behm, J. 2005. On the Verge of Responsible Science. In: Ulrich, H.G., Poltier, J.H., Heuser, S. and Barth, G. (Eds.). Research and responsibility. 28-36. Annual Report. Societias Ethica. European Society for Research in Ethics. ISSN 1814-8204.

Bentham, J. 1907. An introduction to the principles of morals and legislation. Clarendon Press. Library of Economics and Liberty. (http://www. encolib.org/library/Bentham/bnthPML1.html). 12/06/2008.

Bosch, J.T., Seidel, C., Batra, S., Lam, H., Tuason, N., Saljoughi, S., Zhou, H. and Saul, R. 2001. Operon Array-Ready Oligo Sets Provide Sequence-Optimized 70mers for DNA Microarrays. QIAGEN News, Issue No.4: 4-8.

Chadwick, B.J., Coelen, R.J., Sammels, L.M., Kertayadnya, G. and Wilcox, G.E. 1995. Nucleotide Sequence Analysis of Jembrana Disease Virus: a New Bovine Lentivirus Associated with an Acute Disease Syndrome. J. of Genetic and Virology, 76 (7): 1637-1650.

Cota-Gomez, A., Flores, N.C., Cruz, C., Casullo, A., Aw, T.Y., Ichikawa, H., Schaak, J., Scheinmen, R. and Flores, S.C. 2002. The Human Immunodeficiency Virus-1 Tat Protein Activates Human Umbilical Vein Endothelial Cell E-selection Expression via an NF-BDependent Mechanism. J. of Biological Chemistry, 277: 14390-14399.

Habermas. J. 1971. Knowledge and Human Interests. Beacon Press, Boston.

Hartaningsih, N., Dharma, D.M.N., Soeharsono, S. and Wilcox, G.E. 2001. The Induction of a Protective Immunity Against Jembrana Disease in Cattle by Vaccination with Inactivated Tissue-derived Virus Antigens. Veterinary Immunology and Immunopathology, 78: 163-176.

Hartaningsih, N. and Wilcox, G.E. 1996. Jembrana Disease Caused by a Pathogenic Bovine Lentivirus Induction of Protective Immunity in Cattle by Vaccination. Abstract. The $\mathrm{X}^{\text {th }}$ Int. Congress of Virology, Jerusalem, Israel, August 1996.Pp. 258.

Leopold, A. 1949. The Land Ethic. 11pp. In: Excerpts from Sand County Almanac. Aldo Leopold (Ed.). http://luminary.us/leopold/land_ethic.html. 20/04/2009.

Malthus, T.R. 1798. Encyclopedia II - Overpopulation Malthus's Theory. www.experiencefestival. com/a/Overpopulation_-_Malthus_theory/id/ 5359256-87k. 
Mepham, B. 2005. Bioethics: An Introduction for the Biosciences. BEE-j. Vol.6. Oxford University Press. UK: 402pp.

Mill, J.S. 1998. Utilitarianism. (http://www.friesian.com/ bentham.html). 04/20/2009.

Moll, H. 1998. Report of the UNOPS Marketing and Rural Finance Expert. In, Supervision Report, Eastern Islands Smallholder Farming Systems and Livestock Development Project. United Nations Office for Project Services (UNOPS), 18 September 1998. Pp. 65-69.

O’Neill, O. 2002. Trust, Medical Ethics, Autonomy, Bioethics, Bioethics philosophy. In: Autonomy and trust in bioethics. 213pp. Cambridge University Press. UK. http://www.questia.com/ library/book/autonomy-and-trust-in-bioethicsby-onora-oneill.jsp. 04/20/2009.

Soeharsono, S., Wilcox, G.E., Dharma, D.M.N., Hartaningsih, N., Kertayadnya, G. and Budiantono, A. 1995. Species Differences in the Reaction of Cattle to Jembrana Disease Virus Infection. J. of comparative Pathology, 112: 391-402.
Studier, F.W. and Moffatt, B.A. 1986. Use of Bacteriophage T7 RNA Polymerase to Direct Selective High-level Expression of Cloned Genes. J. of Molecular Biology, 189: 113-130.

Wilcox, G.E., Chadwick, B.J. dan Kertayadnya, G. 1995. Jembrana Disease Virus: a New Bovine Lentivirus Producing an Acute Severe Clinical Disease in Bos Javanicus Cattle. Abstract. The $3^{\text {rd }}$ International Congress on Veterinary Virology, Interlaken, Switzerland 4-7 September 1994.

$\mathrm{Wu}, \mathrm{T} .2004$. HIV-1 Gene Expression: Lessons from Provirus and Non-integrated DNA.Review. http://www.retrovirology.com/containt/1/1/13. 04/30/2009.

http://www-history.mcs.st-andrews.ac.uk/Mathematicians/ Avicenna.html. 1999. Biography of Abu Ali alHusain ibn Abdallah ibn Sina (Avicenna) 980 1037. JOC/EFR @ November 1999.04/30/2009. 